\title{
Teori Kepribadian dan Perbedaan Individu
}

\author{
Bisyri Abdul Karim \\ Dosen Tetap Universitas Muslim Indonesia \\ bishriabdulkarim@umi.ac.id
}

\begin{abstract}
Abstrak
Kajian ini bertujuan untuk menemukan teori-teori kepribadian dan perbedaan individu. Adapun latar belakang tulisan ini, adalah bahwa manusia adalah makhluk sosial yang mengandung niat bahwa manusia tidak dapat dipisahkan dari individu lain yang berinteraksi satu sama lain, terutama yang berkaitan dengan interaksi yang disengaja. Perbedaan individu mengenai variasi yang terjadi, baik variasi dalam aspek fisik maupun psikologis. Perbedaanperbedaan ini mempengaruhi perilaku mereka di rumah dan di lingkungan lain. Dalam teori kepribadian, setiap orang secara otomatis mengungkapkan karakteristik yang berbeda dari kepribadian lain. Setiap orang memiliki karakteristik khusus dan unik. Kehidupan seseorang meliputi berbagai aspek, khususnya aspek emosional, aspek psikologis sosial dan sosial budaya, serta kemampuan intelektual yang sepenuhnya terintegrasi ke dalam faktor lingkungan kehidupan.
\end{abstract}

\section{Kata Kunci: Teori Kepribadian; Perbedaan Individu.}

\section{Pendahuluan}

\subsection{Latar Belakang Masalah}

Masalah kepribadian adalah deskripsi (representasi) untuk setiap individu dalam pergaulan. Dalam pergauan itu, ada kontak langsung antara satu individu dan yang lain, dan ini juga terjadi di dunia pendidikan. Interkomunikasi atau kontak langsung antara pendidik dan siswa memungkinkan timbulnya cinta bagi siswa pendidik atau sebaliknya. Meski begitu, harus diakui bahwa setiap individu berbeda dalam hubungannya, bahkan dalam kasus ini, perbedaan ini dapat ditemukan di pendidik pribadi dan di pendidik.

Sebagai makhluk yang berkepribadian, maka manusia adalah home educandum (makhluk yang dapat didik), dan manusia juga sebagai homo education (makhluk yang dapat mendidik). Kedudukan manusia seperti ini menjadikannya sebagai makhluk termulia yang kepadanya dibekali naluri agar menjadi pendidik yang kodrati dalam bentuk dorongan untuk melindungi, dan atau memelihara, serta mendidik anak-anaknya dan orang lain. Dengan demikian, maka manusia adalah makhluk individu dan makhluk sosial yang harus berinteraksi dengan selainnya.

Dalam hubungannya dengan manusia sebagai makhluk sosial, ada suatu maksud bahwa manusia tidak dapat dipisahkan dari individu lain yang berinteraksi satu sama lain, terutama yang berkaitan dengan interaksi yang disengaja, jadi mari kita bicara tentang interaksi pendidikan. Interaksi pendidikan ini adalah interaksi yang terjadi dalam koneksi untuk tujuan pendidikan.

Pendidikan merupakan kebutuhan pokok bagi manusia dalam upaya menentukan hidupnya. Pendidikan tersebut berlangsung seumur hidup (long life education). Pendidikan dilaksanakan dalam lingkungan keluarga, sekolah, dan masyarakat. Kesempatan berinteraksi setiap individu dengan individu lainnya dalam dunia pendidikan wajib diadakan dan dipergunakan dengan sebaiknya, karena dengan begitu, akan menimbulk an hubungan wajar antara kekuasaan pendidik dan ketaatan anak didik. Dari interaksi seperti ini, maka pada gilirannya ada saling pengaruh dan mempengaruhi.

Adanya saling pengaruh dan mempengaruhi antara individu dengan individu lainnya, akan bermuara pada adanya kepribadian dan perbedaan antara individu. Terma kepribadian dan perbedaan individu, memiliki arti yang berbeda namun keduanya sangat berkaitan. 


\subsection{Rumusan Masalah}

Berdasarkan uraian-uraian pada latar belakang yang telah dipaparkan, maka pokok masalah yang menjadi obyek pada kajian ini, adalah bagaimana teori-teori kepribadian dan perbedaan individu?

Untuk uraian lebih lanjut, maka pokok masalah yang telah ditetapkan, dapat dirinci ke dalam dua sub permasalahan yakni ;

1. Bagaimana teori kepribadian?

2. Bagaimana teori perbedaan individu ?

\section{Pembahasan}

\subsection{Kepribadian dalam Teori Pendidikan Islam}

Istilah kepribadian secara etimologis, berasal dari kata "pribadi" yang berarti manusia sebagai perseorangan, yang meliputi keseluruhan sifat-sifat dan watak yang dimilikinya. ${ }^{1}$ Jika kata dimulai dengan afiks "ke" akhiran "an" yaitu "ke-pribadi-an", maka artinya adalah karakteristik sifat hakiki yang mencerminkan tindakan seseorang.

Adapun pengertian kepribadian dalam istilah terminologis, ada berbagai definisi yang dikutip oleh Dr. Sarlito Wirawan, yakni;

1. Kepribadian adalah kumpulan sifat biologis dalam bentuk dorongan, kecenderungan, rasa dan naluri yang terganggu di alam dan kecenderungan diperoleh melalui pengalaman yang ditemukan pada seseorang.

2. Kepribadian adalah keseluruhan organisasi yang ditemukan pada manusia, di semua tingkat perkembangan.

3. Kepribadian adalah tingkat sifat yang biasanya merupakan sifat tingkat tinggi yang memiliki pengaruh yang menentukan.

4. Kepribadian adalah integrasi dari sistem kebiasaan yang menunjukkan kepada individu cara unik untuk beradaptasi dengan lingkungan mereka. ${ }^{2}$

Dari batasan-batasan definisi di atas, ditemukan dua kata kunci mengenai kepribadian, yakni "sifat" dan "sikap". Namun jika kita lebih menafsirkannya, tentu saja ada kata-kata kunci lain yang sangat terkait dengan kepribadian, misalnya; ciri-ciri, karakter, karakter, jiwa, moral, roh, kebiasaan dan perilaku. Dari kata-kata kunci ini, kita dapat merumuskan bahwa kepribadian adalah psiko dan organisasi fisik yang dinamis dari setiap manusia yang menentukan adaptasinya yang unik terhadap lingkungannya.

Bedasarkan teori kepribadian, setiap orang memiliki karakteristik khusus dan unik. Kehidupan manusia meliputi aspek keanekaragaman, termasuk aspek emosional, sosial,

${ }^{1}$ Departemen Pendidikan dan Kebudayaan, Kamus Besar Bahasa Indonesia, Edisi III (Cet. II; Jakarta: Balai Pustaka, 2002), h. 895

${ }^{2}$ Sarlito Wirawan Sarwono, Pengantar Umum Psikologi (Cet. VI; Jakarta: Bulan Bintang, 1991), h. 79 
psikologis, dan sosial budaya, provinsi, di mana kapasitas mental terintegrasi secara terpusat dengan faktor lingkungan. Keunikan kehidupan pribadi berarti bahwa semua kebutuhannya harus dipenuhi dan dihubungkan dengan masalah yang tidak dapat diasimilasi dengan orang lain. Dengan demikian, setiap individu mengungkapkan karakteristik yang secara alami berbeda dari kepribadian lain. Selain itu, dunia ini membutuhkan keharmonisan antara kebutuhan fisik dan non-fisik.

Kebutuhan fisik setiap orang harus terpenuhi, misalnya seseorang perlu bernapas dengan bebas, perlu makan dengan baik dan cukup, membutuhkan kesenangan dan membutuhkan keamanan. Dalam kaitannya dengan aspek sosial-psikologis, setiap orang membutuhkan kemampuan untuk menguasai sikap dan emosi mereka sendiri, serta struktur komunikasi untuk bersosialisasi. Itu semua akan tampak lengkap dan lengkap dalam bentuk hubungan dan perilaku konstan. Oleh karena itu, masalah teori kepribadian membentuk bentuk antara faktor fisik, sosial-budaya dan psikologis. Selain itu, setiap orang juga membutuhkan persetujuan pihak lain atas kebanggaan mereka, baik dari rumah mereka maupun dari luar rumah.

Ketika teori kepribadian dikaitkan dengan teori pendidikan, maka ditemukan adanya integrasi. Dalam GBHN (Keputusan MPR No. IV / MPR / 1978) berikut ini dinyatakan tentang pendidikan: "Pendidikan berlangsung seumur hidup dan berlangsung di keluarga, sekolah dan masyarakat. Oleh karena itu, pendidikan adalah tanggung jawab bersama antara keluarga, masyarakat. dan pemerintah.

Tanggung jawab untuk pendidikan dipenuhi dengan kewajiban untuk mendidik. Secara umum, itu adalah untuk melatih siswa untuk mengembangkan kemampuan mereka dan untuk menentukan nilai-nilai yang pada akhirnya dapat mempengaruhi kepribadian siswa ke arah yang lebih baik. Bantuan atau bimbingan diberikan dalam hubungan antara pendidik dan siswa dalam situasi pendidikan yang ada di rumah tangga, sekolah dan masyarakat. Kepemimpinan aktif dan pasif. Dikatakan "pasif", yang berarti bahwa pendidik tidak melanjutkan dengan "periode sensitif" tetapi menunggu dengan sabar dan sabar. Bimbingan aktif terletak secara internal :

a. Pengembangan daya-daya yang sedang mengalami masa pekanya.

b. Pemberian pengetahuan dan kecakapan yang penting untuk masa depan si anak, dan

c. Membangkitkan motif-motif yang dapat menggerakkan si anak untuk berbuat sesuai dengan tujuan hidupnya. ${ }^{3}$

Faktor yang mempengaruhi kepribadian anak adalah pengaruh pendidikan keluarga. Orang tua adalah pendidik pertama dan pertama untuk anak-anak mereka, karena berasal dari mereka bahwa anak-anak menerima pendidikan terlebih dahulu. Karena itu, bentuk pendidikan pertama kali terjadi dalam kehidupan keluarga. Secara umum, pendidikan domestik tidak berasal dari kesadaran dan pemahaman yang lahir dari pengetahuan pendidikan, tetapi dari sifat atmosfer dan struktur, itu adalah kemungkinan alami untuk membangun situasi pendidikan. Situasi pendidikan tercapai berkat asosiasi dan pengaruh saling pengaruh antara orang tua dan anak-anak.

${ }^{3}$ Zakiah Daradjat, Ilmu Pendidikan Islam, Cet; III (Jakarta: Bumi Aksara, 1996), h. 34-35 
Orang tua atau ibu dan ayah memainkan peran penting dan sangat berpengaruh dalam kepribadian anak-anak. Sejak anak itu lahir, ibunya selalu ada di sampingnya. Karena itu, anak-anak menyetujui perang, setuju bahwa ibu melakukan pekerjaannya dengan baik. Pengaruh citra ayah pada tulang besar juga. Di mata keturunannya, ayah dari seseorang yang memiliki gengsi tertinggi dan paling cerdas di antara orang-orang yang dikenalnya. Cara ayah melakukan pekerjaan sehari-hari hanya pada hari kerja.

Tanggung jawab pendidikan Islam yang menjadi beban orang tua sekurangkurangnya harus dilaksanakan dalam rangka :

a. Memelihara dan membesarkan anak.

b. Melindungi dan menjamin kesamaan.

c. Memberi pengajaran dalam arti yang luas sehingga anak memperoleh peluang untuk memiliki pengetahuan dan kecakapan serta berkepribadian.

d. Membahagiakan anak, baik dunia maupun akhirat sesuai dengan pandangan dan tujuan hidup muslim. ${ }^{4}$

Mengenai kewajiban dan tanggung jawab orang tua untuk mendidik dan membimbing perkembangan anak-anaknya dijelaskan oleh Imam Gazali bahwa :

Anak itu pada hari ke tujuh dari kelahirannya disembelihkan akikahnya, serta diberi namanya dan disingkirkan dari segala kotoran-kotoran. Jika ia telah berumur 6 tahun ia didik beradab susila, jika ia telah berumur 9 tahun dipisahkan tempat tidurnya dan jika telah berumur 13 tahun dipukul agar mau sembahyang (diharuskan). Bila ia telah berumur 16 tahun boleh dikawinkan, setelah itu ayah berjabatan tangan dengannya dan mengatakan : "Saya telah mendidik, mengajar dan mengawinkan kamu, saya mohin perlindungan kepada Allah dari fitnahan-fitnahan di dunia dan siksaan di akhirat...."

Sesuai dengan tugasnya, keluarga dalam melaksanakan misinya sebagai penyelenggara pendidikan, bertanggung jawab mengutamakan pembentukan pribadi anak.

Dari sudut pandang pendidikan Islam, sesuatu tidak dapat dijalani dan dipraktikkan jika hanya diajarkan tetapi harus diajarkan melalui proses pendidikan. Nabi meminta orang untuk percaya dan melakukan perbuatan baik dan moral yang sesuai dengan ajaran Islam dengan berbagai metode dan pendekatan. Dari sudut pandang tertentu, kami percaya bahwa pendidikan Islam lebih fokus pada peningkatan sikap mental / kepribadian yang dinyatakan dalam amal untuk kebutuhan diri sendiri dan orang lain. Di samping itu. Pendidikan Islam mengajarkan tidak hanya teori tetapi juga praktis. Ajaran Islam tidak memisahkan keyakinan pada perbuatan baik. Oleh karena itu, pendidikan Islam adalah pendidikan agama dan amal. Dan karena ajaran Islam termasuk ajaran tentang sikap masyarakat dan perilaku pribadi terhadap kesejahteraan individu dan kehidupan masyarakat, pendidikan Islam dengan demikian merupakan pendidikan individu dan masyarakat. Awalnya, orang-orang yang bertanggung jawab atas pendidikan adalah para

\footnotetext{
${ }^{4}$ Ibid., h. 38.
}

${ }^{5}$ Hujjatul Islam Abu Hamid Imam al Gazaly, Ihya Ulumuddin, jilid II (Makkah al-Mukarramah: Dār al-Qalam, 1978), h. 217 
nabi dan rasul, kemudian belajar dan memberi energi dalam tugas dan tanggung jawab pengikut mereka..

Setiap orang harus mengamalkan ajaran-ajaran agama agar mereka memiliki kepribadian yang islami dalam arti yang seluas-luasnya. Kepribadian yang demikian ini, tergambar pada diri Nabi saw, sebagaimana yang ditegaskan dalam QS. al-Ahzāb (33): 21, yakni ;

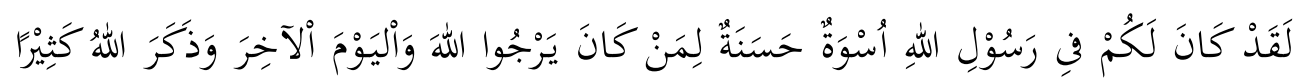

Terjemahnya:

Sesungguhnya telah ada pada (diri) Rasulullah itu suri teladan yang baik bagimu (yaitu) bagi orang yang mengharap (rahmat) Allah dan (kedatangan) hari kiamat dan dia banyak menyebut Allah. ${ }^{6}$

Berdasar ayat di atas, maka umat Islam harus mengarahkan dirinya untuk berkepribadian Islami, yakni berkepribadian muslim dengan cara mencontoh Nabi saw sebagai uswah al-hasanah, dan tentu saja hal ini ini dapat tercapai bilamana konsep pendidikan Islam berjalan dengan baik. Dikatakan demikian, karena tujuan utama pendidikan Islam adalah terwujudnya kepribadian muslim.7 Tujuan seperti ini, dirumuskan juga dalam Undang-undang Sisdiknas yakni ;

Pendidikan nasional bertujuan untuk mengembangkan potensi peserta didik untuk menjadi manusia yang beriman dan takut kepada Tuhan Yang Maha Esa, berakhlak mulia, sehat, berpengetahuan luas, mampu, kreatif, mandiri dan menjadi warga negara yang demokratis dan bertanggung jawab. ${ }^{8}$

Klausa "manusia yang beriman dan bertakwa" yang dimaksud dalam Undangundang Sisdiknas di atas, tentu saja sasarannya adalah pada pembentukan pribadi muslim. Hal ini sejalan dengan firman Allah dalam QS. Āli Imrān (3): 102, sebagai berikut :

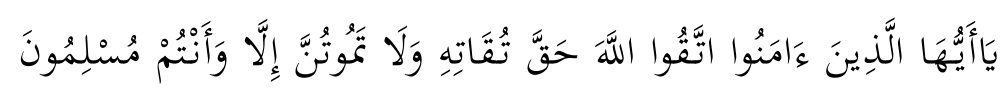

Terjemahnya :

Hai orang-orang yang beriman, bertakwalah kepada Allah sebenar-benar takwa kepada-Nya; dan janganlah sekali-kali kamu mati kecuali dalam keadaan beragama Islam. ${ }^{9}$

Kewajiban bagi orang beriman untuk menjadi religious yang mengarah kepada seorang Muslim, sebagaimana ditunjukkan dalam ayat di atas, yang berarti bahwa orang beriman harus mengolah sifat taqwa sendiri. Dalam spiritualitas yang berkembang pesat, kepribadian

${ }^{6}$ Departemen Agama RI, Al-Qur'an dan Terjemahnya (Jakarta: Proyek Pengadaan Kitab Suci al-Qur'an, 1992), h. 670.

${ }^{7}$ Ishāāq Ahmad Farhān, al-Tarbiyah al-Islāmiyah bayn al-Așālah wa al-Ma'āsirah (Cet. II; t.tp: Dār al-Furqān, 1983), h. 30

${ }^{8}$ Lihat Undang-Undang RI N0. 20 Tahun 2003 tentang SISDIKNAS (Cet. II; Bandung: Fokus media, 2003.

${ }^{9}$ Departemen Agama RI, op. cit., h. 92 
Muslim lahir. Dengan kata lain, melalui iman dan kekudusan, kepribadian Muslim berkembang. Karena itu, orang yang beriman dan tidak beragama adalah citra pria Muslim.

Masih mengenai penjelasan ayat tersebut, Prof. Dr. Zakiah Daradjat mengatakan bahwa mati dalam penyerahan diri kepada Tuhan sebagai seorang Muslim adalah akhir dari kesalehan, karena akhir dari proses kehidupan jelas mengandung kegiatan pendidikan. Lebih lanjut, pakar pendidikan ini menjelaskan bahwa sesuatu yang harus diwujudkan setelah orang-orang telah mengalami pendidikan Islam secara keseluruhan, yaitu kepribadian seseorang yang menjadikannya seorang "manusia" dengan model kesalehan. Insan kamil berarti bahwa orang itu spiritual dan secara fisik utuh, mampu hidup dan berkembang secara alami dan normal karena taqwa mereka. ${ }^{10}$

Di samping kepribadian muslim secara khusus, Alquran juga mem-bicarakan tentang kepribadian manusia secara umum dengan berbagai karakteristik-nya, yang membedakan manusia dari makhluk-makhluk Allah lain. Selain itu Alquran juga menerangkan modelmodel atau pola-pola umum kepribadian manusia yang diwarnai dengan sifat-sifat utama, yaitu pola-pola umum yang dapat ditemui di masyarakat. Di sisi lain, dalam Alquran juga terdapat uraian tentang kepribadian yang lurus dan tidak lurus, juga terdapat uraian tentang berbagai faktor yang membentuk kepribadian, baik yang lurus maupun yang tidak. ${ }^{11}$

Dalam kepribadian manusia, terkandung berbagai sifat hewani yang tercermin dalam berbagai kebutuhan fisik yang harus dipenuhinya demi kelangsungan hidup dirinya. Selain itu, dalam kepribadiannya juga terkandung berbagai sifat malaikat, yang tercerminkan dalam kerinduan spiritualnya untuk mengenal Allah. Kadang-kadang antara kedua kepribadian ini terjadi konflik, sehingga kadang-kadang ia tertarik oleh kebutuhan-kebutuhan dan hawa nafsu fisiknya, dan kadang-kadang tertarik oleh kebutuhan-kebutuhan dan kerinduan spiritualnya. Akibatnya, dalam dirinya ia merasakan terjadinya konflik antara kedua aspek kepribadian itu. Dari sini, maka dipahami bahwa dalam diri manusia terdapat kesiapan untuk melakukan kebajikan dan kejahatan, mengikuti hawa nafsu fisiknya tenggelam dalam kenikmatan inderawinya dan berbuat berbagai keinginan duniawaniya. Kepribadian fisik seperti ini, sungguh sangat tercelah dan menyimpang dari kepribadian muslim. Dalam QS. al-Nāzi'āt (79): 37-41,

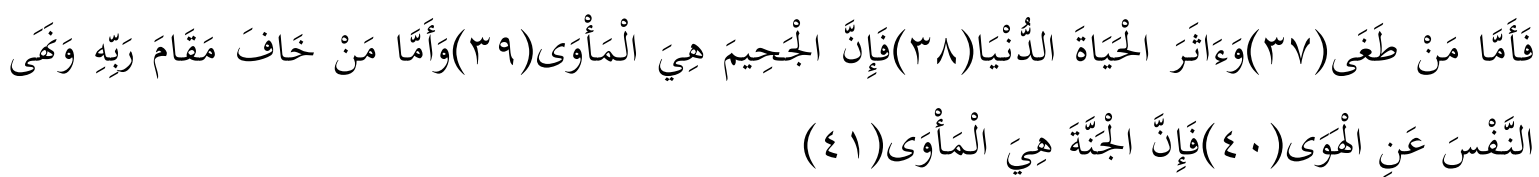

Terjemahnya :

Adapun bagi mereka yang melampaui batas dan memprioritaskan kehidupan dunia, maka sesungguhnya nerakalah tempat tinggalnya. Maka sesungguhnya nerakalah tempat tinggalnya. Dan bagi mereka yang takut akan kebesaran Tuhan mereka dan menahan diri dari keinginan nafsu mereka, maka sesungguhnya surgalah tempat tinggal yang sebenar-benarnya. ${ }^{12}$

${ }^{10}$ Ibid., h. 29

${ }^{11}$ Muhammad Utsman Najati, al-Qur'ān wa 'Ilm al-Nafs diterjemahkan oleh Ahmad Rofi', Usmani dengan judul Al-Qur'an dan Ilmu Jiwa (Cet. I; Bandung: Pustaka, 1985), h. 240

${ }^{12}$ Departemen Agama RI, op. cit., h. 1022 
Dalam konteks ayat di atas, jelaslah bahwa kepribadian secara redaksional yakni khawf (takut) yang identik dengan takwa merupakan bentuk pribadi yang dapat mengekang hawa nafsunya dari sifat dan sikap negatif yang membahayakan dirinya dan orang lain .

Membicarakan kepribadian, oleh kebanyakan pakar menganggapnya sebagai pengaruh yang ditimbulkan seseorang atas diri orang lain, atau sebagai kesan utama yang ditinggalkan seseorang pada orang lain. Misalnya sebagai pribadi agresif atau berpribadi pendamai. Sebagiannya menganggap bahwa kepribadian sebagai struktur dan proses kejiwaan tetap yang mengatur pengalaman-pengalaman seseorang membentuk tindakan-tindakan dan respons-nya terhadap lingkungannya, dalam cara yang membedakannya dari orang lain .

Lingkungan memiliki peran yang sangat penting dalam keberhasilan pendidikan Islam, karena perkembangan seseorang sangat dipengaruhi oleh lingkungan. Lingkungan dapat memiliki pengaruh positif dan negatif pada pertumbuhan dan perkembangan sikap, adat istiadat dan perasaan agama. Orang dapat memahami bahwa penerapan pendidikan Islam yang benar di setiap bidang pendidikan memiliki peran penting dalam pembentukan kepribadian. Dengan demikian suksesnya lembaga pendidikan melaksanakan peranannya sangat tergantung pula pada keadaan lingkungan pendidikan. Sebagaimana halnya pendidikan pada umumnya, maka pendidikan Islam juga berlangsung dalam rumah tangga, sekolah dan masyarakat. Dalam hal ini, manusia sejak lahir, telah berinteraksi dengan lingkunganya. Ia dipengaruhi oleh lingkungan dan sebaliknya ia mempengaruhi lingkungan.

Adapun sasaran tujuan pendidikan adalah sebagai berikut :

1. Pembinaan kepribadian anak didik yang sempurna :

a. Pendidikan harus membentuk kekuatan dan kesehatan badan dan otak (pikiran) anak didik.

b. Sebagai individu, maka anak itu harus dapat mengembangkan kemampuan semaksimal mungkin.

c. Sebagai anggota masyarakat, maka harus dapat mempunyai tanggung jawab sebagai warga negara yang baik.

d. Sebagai pekerja, maka anak itu harus bersifat efektif produktif dan cinta akan kerja.

3. Peningkatan Moral, tingkah laku yang baik dan menanamkan rasa kepercayaan anak pada agama dan kepada Tuhan.

4. Mengembangkan integensi anak secara efektif dan pengertian anak didik tentang peran mereka di masa mendatang.

\subsection{Analisis tentang Perbedaan Individual}

Individual diartikan sebagai perseorangan. ${ }^{13}$ Seperti Lysen, ia mendefinisikan individu sebagai "individu", sesuatu yang merupakan keseluruhan yang tidak dapat dibagi (secara terpisah). Setiap orang, anak-anak atau orang dewasa, baik dalam kelompok maupun sendiri, disebut individu. Oleh karena itu, individu menunjukkan posisinya sebagai individu. Sejauh sifat individu yang bersangkutan, itu adalah sifat relatif terhadap individu, dalam kaitannya

${ }^{13}$ Departemen Pendidikan dan Kebudayaan, op. cit., h. 430 
dengan perbedaan individu individu. Karakteristik dan karakteristik seseorang berbeda dari yang lain. Perbedaan-perbedaan ini disebut perbedaan individu atau perbedaan individu .

Setiap anak yang dilahirkan telah memiliki potensi yang berbeda atau menjadi miliknya sendiri. Tidak ada individu yang identik di muka bumi. Masing-masing memiliki individualitas. Ketika datang ke kembar dipasangkan dari telur yang sama, umumnya seperti pinang dipotong menjadi dua, lebih disukai dan sulit untuk dibedakan satu sama lain, hanya mirip tetapi tidak identik, mereka identik. Ini berlaku untuk karakteristik fisiknya dan kehidupan psikiatrisnya.

Secara fisik, mungkin bentuknya sama dengan wajah. Secara spiritual, mungkin kapasitas kecerdasannya sama, tetapi kecenderungan, antusiasme, dan daya tahannya berbeda. Dalam kehidupan sehari-hari dua siswa dengan nama yang sama tidak pernah setuju untuk disamakan satu sama lain. Singkat kata, masing-masing ingin mempertahankan karakter tersendiri.

Berdasarkan uraian di atas, dapat dirumuskan bahwa makna perbedaan dalam istilah "perbedaan individu" terkait dengan variasi yang terjadi, baik dengan variasi aspek fisik dan psikologis. Perbedaan-perbedaan ini mempengaruhi perilaku mereka di rumah dan di lingkungan lain, seperti sekolah. Gejala dapat diamati ketika mereka menjadi lebih atau kurang di beberapa daerah dibandingkan dengan yang lain. Beberapa manusia lebih mampu dalam bidang kognitif atau bidang ilmu terkait. Untuk perincian lebih lanjut, dijelaskan aspek-aspek perbedaan individu berikut ini.

\section{Perbedaan Kognitif}

Kemampuan kognitif adalah kemampuan yang terkait dengan penguasaan sains dan teknologi. Pada dasarnya keterampilan kognitif adalah hasil belajar. Seperti yang kita ketahui, hasil belajar adalah kombinasi dari faktor bawaan dan pengaruh lingkungan (faktor dasar dan faktor pengajaran). Faktor dasar yang memiliki pengaruh signifikan terhadap kemampuan kognitif dapat dibedakan dalam bentuk lingkungan alami dan lingkungan yang diciptakan.

\section{Perbedaan Kecakapan Bahasa}

Kemampuan masing-masing individu dalam bahasa berbeda, masing-masing individu mengekspresikan pemikirannya dalam bentuk kata-kata dan frase yang bermakna dengan cara yang sangat berbeda. Keterampilan berbahasa sangat dipengaruhi oleh faktor kecerdasan dan lingkungan. Faktor penting lainnya juga faktor fisik, khususnya organ yang berbicara.

\section{Perbedaan Kecakapan Motorik}

Keterampilan motorik, atau keterampilan psikomotorik, adalah kemampuan untuk mengoordinasikan kerja saraf motorik oleh saraf pusat untuk melakukan aktivitas. Kegiatan ini terjadi karena kerja saraf yang sistematis. Organ sensorik menerima rangsangan, rangsangan ditransmisikan oleh saraf sensorik ke pusat otak untuk diproses, dan hasilnya diangkut oleh saraf motorik untuk memberikan reaksi dalam bentuk gerakan atau kegiatan. 
4. Perbedaan Latar Belakang

Dalam kelompok siswa di semua tingkatan, perbedaan latar belakang dan pengalaman mereka dapat memfasilitasi atau menghambat hasil mereka, terlepas dari potensi individu untuk menguasai materi pembelajaran.

Minat dan sikap individu terhadap sekolah dan mata pelajaran tertentu, pendekatan kolaboratif, keterampilan atau kemauan untuk fokus pada materi pembelajaran dan cara belajar adalah semua faktor yang berbeda di antara siswa. Terkadang faktor-faktor ini dapat berkembang karena perbedaan sikap anggota keluarga di rumah dan lingkungan sekitarnya.

\section{Perbedaan Bakat}

Bakat adalah kemampuan khusus yang dikenakan sejak lahir. Kemampuan ini akan berkembang dengan baik pada stimulasi dan pemupukan yang tepat. Pengembangan bakat siswa adalah individu. Meskipun kecerdasan umum merupakan faktor di hampir semua atau bahkan semua bidang penampilan atau kinerja, hasil tes kecerdasan yang telah dilakukan lebih berkaitan dengan prestasi atau kemampuan akademik. Dengan demikian, perencanaan pendidikan, pada gilirannya, lebih mementingkan kapasitas atau bakat akademis daripada kapasitas tentang bakat khusus yang akan digunakan sebagai dasar untuk refleksi.

\section{Perbedaan Kesiapan Belajar}

Siswa berusia enam tahun yang memasuki sekolah dasar (kelas I) mungkin berbeda satu, dua atau bahkan tiga tahun dalam hal kesiapan mereka untuk belajar di lembaga pendidikan formal. Ini didasarkan pada kapasitas mental atau usia mental, karena anakanak di tahun pertama sekolah dasar termasuk dalam kelompok usia kronologis antara tiga dan delapan tahun. Ini berarti bahwa meskipun usia kronologis telah mencapai delapan tahun, tetapi kemampuan untuk belajar selalu sama dengan mereka yang duduk di tahun pertama. Ini menunjukkan kurangnya produk keluarga, yang kemungkinan besar ekspresi bahasa dan kehidupan keluarga tidak baik.

\section{Kesimpulan}

Berdasarkan masalah yang diidentifikasi dan hubungannya dengan deskripsi yang dijelaskan sebelumnya, dapat disimpulkan bahwa dalam teori kepribadian, setiap orang secara otomatis menyajikan karakteristik yang berbeda dengan kepribadian lainnya. Setiap orang memiliki kepribadian yang unik dan unik. Kehidupan seseorang melibatkan berbagai aspek, terutama aspek emosional, sosial, psikologis dan sosial-budaya, serta kapasitas intelektual yang sepenuhnya terintegrasi dengan faktor-faktor lingkungan kehidupan.

Manusia sebagai makhluk individu, yakni "orang-seorang" yang merupakan suatu keutuhan dan tidak dapat dibagi-bagi yang lazimnya disebut person. Setiap individu memiliki perbedaan dengan individu lainnya. Orang kembar, secara fisik mungkin bentuk muka sama tetapi terdapat perbedaan mengenai matanya. Secara kerohanian mungkin kafasitas intelegensinya sama, tetapi kecenderungan, semangat, dan daya tahan yang berbeda. Adapun aspek-aspek perbedaan individual meliputi, perbedaan kognitif, perbedaan kecakapan bahasa, perbedaan kecakapan motorik, perbedaan latar belakang, perbedaan bakat, perbedaan kesiapan belajar. 


\section{DAFTAR PUSTAKA}

AL-Qur'ān al-Karīm

Arifin, H. M. Hubungan Timbal Balik Pendidikan Agama di Lingkungan Sekolah dan Keluarga. Jakarta: Bulan Bintang, 1978

Daradjat, Zakiah. dkk. Ilmu Pendidikan Islam. Cet. III; Jakarta: Bumi Aksara bekerja-sama dengan Direktorat Jenderal Pembinaan Kelembagaan Agama Islam, 1996 . Remaja; Harapan dan Tantangan. Cet. I; Jakarta: Ruhama, 1994.

Departemen Agama RI, Al-Qur'an dan Terjemahnya. Jakarta: Proyek Pengadaan Kitab Suci alQur'an, 1992

Departemen Pendidikan dan Kebudayaan, Kamus Besar Bahasa Indonesia, Edisi III. Cet. II; Jakarta: Balai Pustaka, 2002

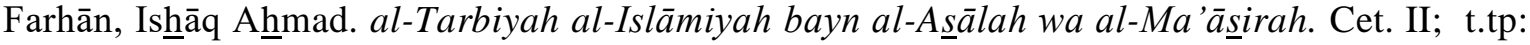
Dār al-Furqān, 1983

Al-Gazaly, Hujjatul Islam Abu Hamid Imam. Ihya Ulumuddin, jilid II. Makkah alMukarramah: Dār al-Qalam, 1978.

Jalaluddin. Psikologi Agama. Cet. VI; Jakarta: PT. RajaGrafindo Persada, 2002.

Marimba, Ahmad D. Pengantar Filsafat Pendidikan Islam. Cet. VIII: Bandung: PT. Al-Ma'arif, 1989

Najati, Muhammad Utsman. al-Qur'ān wa 'Ilm al-Nafs diterjemahkan oleh Ahmad Rofi' Usmani dengan judul Al-Qur'an dan Ilmu Jiwa. Cet. I; Bandung: Pustaka, 1985

Nurwanita Z, Ilmu Jiwa Perkembangan. Makassar: Yayasan Pendidikan Makassar, 2005.

Ramayulis, Ilmu Pendidikan Islam. Cet. I; Jakarta: Kalam Mulia, 1994

Sarwono, Sarlito Wirawan. Pengantar Umum Psikologi. Cet. VI; Jakarta: Bulan Bintang, 1991

Sujanto, Agus. Psikologi Perkembangan. Cet. VII; Jakarta: Rineka Cipta, 1996

dan Halem Lubis, Taufid Hadi, Psikologi Kepribadian. Cet. VII; Jakarta: Bumi Aksara, 1997.

Sunarto, H. dan Ny. B. Agung Hartono, Perkembangan Peserta Didik. Cet. II; Jakarta: Rineka Cipta, 2002.

Tirtaharja, Umar dan La Sula, Pengantar Pendidikan. Jakarta: Rineka Cipta, 2001

Undang-Undang RI N0. 20 Tahun 2003 tentang SISDIKNAS. Cet. II; Bandung: Fokus Media, 2003. 